\title{
Antimicrobial and Antifungal Effect of Ginger (Zingiber officinale), Green Tea (Camellia sinensis) And Neem (Azadirachta indica) On Plant Pathogens
}

\author{
Salman Shahid ${ }^{1 \ddagger}$, Tahir Naqqash ${ }^{2 \ddagger *}$, Kashif Aslam², Muhammad Kashif Hanif ${ }^{3}$, Muther Mansoor \\ Qaisrani ${ }^{4}$ and Ghulam Shabir ${ }^{2 *}$
}

${ }^{1}$ Department of Molecular Biology, Virtual University, Pakistan

${ }^{2}$ Institute of Molecular Biology and Biotechnology, Bahauddin Zakariya University, Pakistan

${ }^{3}$ Institute of Molecular Biology and Biotechnology, University of Lahore, Sargodha Campus

${ }^{4}$ Department of Bioinformatics, Khwaja Fareed University of Engineering and Information Technology, Pakistan

*Corresponding author: Tahir Naqqash and Ghulam Shabir, Bahauddin Zakariya University, Multan, Pakistan Institute of Molecular Biology and Biotechnology, Bahauddin Zakariya University, 60800 Multan, Pakistan.

To Cite This Article: Salman Shahid1f, Tahir Naqqash, Kashif Aslam, Muhammad Kashif Hanif, Muther Mansoor Qaisrani, Ghulam Shabir. Antimicrobial and Antifungal Effect of Ginger (Zingiber officinale), Green Tea (Camellia sinensis) And Neem (Azadirachta indica) On Plant Pathogens. Am J Biomed Sci \& Res. 2021 - 14(3). AJBSR.MS.ID.001995. DOI: 10.34297/AJBSR.2021.14.001995.

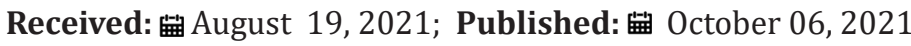

\begin{abstract}
Plants have been the source of food, medicines and many other daily life products since primitive times. Bacterial and fungal pathogenic attack reduces crop yield. Phytochemicals as biocides have ability to kill microbes. In this study, extract of Zingiber officinale rhizomes (Ginger), leaves of Azadirachta indica (Neem) and Camellia sinensis (Green tea) were applied on bacterial (Xanthomonas campestris) and fungal (Alternaria alternata) pathogens to check their antibacterial and antifungal activity, respectively. Ethanolic and aqueous extracts were prepared which showed different efficiency. Bacterial pathogen was grown on "Nutrient agar (NA) media" while fungal pathogen was grown on "Potato dextrose agar (PDA) media". Antibacterial and antifungal potential of plant extracts were observed at two different stages (at the time of inoculation and after growth of pathogen on media). The inhibition zone was assessed by "agar-well diffusion method" and MIC was measured by "micro-broth dilution method". Ethanolic extract of green tea showed highest inhibition zone for Xanthomonas compestris while aqueous extract showed lowest inhibition zone. Moreover, highest antifungal activity was also shown by aqueous extract of green tea leaves. However, aqueous extract of ginger rhizome showed no antifungal activity. The lowest antibacterial and antifungal activity was showed by the ethanolic and aqueous extract of neem, respectively. MIC of aqueous extract of ginger rhizome was highest for fungal pathogen; however, the lowest MIC value for Alternaria alternata was due to ethanolic extract of neem leaves. This study gave us basis for making disease control strategies for pathogens of economically important crops such as X. campestris and A. alternata. Our findings will also help the management for effective disease control implementations.
\end{abstract}

Keywords: Aqueous extract; Ethanolic extract; Inhibition zone; Minimum Inhibitory Concentration; Antimicrobial activity; Antifungal activity; Xanthomonas campestris; Alternata

Abbreviation: MIC: Minimum Inhibitory Concentration

\section{Introduction}

Before the era of scientific research in the field of plant pathology, there was nothing to control plant diseases. Plants were growing in close proximity and protect each other from harmful pathogens. Ancient humans living in wild environment had used plants and plant extracts as a source of medicine, food, aromatic products.
When scientific research started in the field of plant sciences, the traditional agriculture system was replaced by modern one. In modern agricultural system synthetic agrochemicals are being used to prevent crop diseases. No doubt this brings revolution in agriculture field by controlling diseases and increasing crop yield vice versa these chemicals are not eco-friendly, so results 
are damaging of natural environment. With the passage of time pathogens developed immunity against agrochemicals and thus there is less control of diseases even by using high concentration of chemicals. There is a need to stop use of agrochemicals and traditional agriculture system must be used to save environment from carcinogens present in agrochemicals. Recently a new idea has evolved in which plant extracts are being used as biocides [1,2]. Extract of some plants show inhibitory effect against pathogenic microbes due to presence of certain bio-chemicals. Now agriculture scientists are considering using these Phytochemicals against microbial pathogens. Pathogenic microbes may cause diseases in plants or animal and may belong to bacterial pathogenic group of microbes or fungal pathogens. Plants use those Phytochemicals as defense against plant pathogens for themselves or for other plants as well.

Every year major loss in crop yield is due to bacterial or fungal attack on commercial crops. Not all but some plants have the characteristics to produce secondary metabolites. These metabolites may have special flavor and odor which may not be favorable for bacterial or fungal growth. These secondary metabolites are known as Phytochemicals. These Phytochemicals help plant for self-defense against attacking microbes and insects or these Phytochemicals may attract insects or microbes for pollination or for other benefits [3]. Use of plants and their products as biocides is getting attention of scientists due to their eco-friendly nature and natural elimination source of toxic food from human food chain. Now scientists are moving from synthetic to natural way of crop protection from bacterial and fungal pathogens [4] From herbs, the phytochemicals are obtained in higher quantity than other plant families i.e. coriander, basil, thyme, onion, ginger, turmeric, garlic, etc. yield phytochemicals with strong antibacterial, antifungal, anti-allergic, antioxidant and chemo-preventive properties [5]. Worldwide there are more than 400,000 species of plants having Phytochemicals with antibacterial, antifungal and antiviral properties [6]. Around $20 \%$ of known plant species are being used in the pharmaceutical fields [7].

Ginger (Zingiber officinale) is a perennial, herbaceous, monocotyledonous plant, cultivated in tropical and sub-tropical area worldwide. Rhizome of ginger has pungent taste and smell, it is mostly used as food additive [6]. It's antibacterial and antifungal properties are due to the Phytochemicals found in the rhizome. The chemical constituents of ginger extract and essential oil are the poly-phenolic ketones called gingerols or Oleoresin [8]. The antifungal effect of ginger is due to gingerone, dihydrogingerone and dehydroshogaol [9]. There are also some other alkaloids, terpenes and terpenoid derivatives having antimicrobial activities on different bacterial pathogens.
Green Tea (Camellia sinensis) is ever green shrubby plant with bright green leaves cultivated in tropical to subtropical region with humid climate and heavy rainfall areas. It shows antibacterial activity against some bacteria which is due to the presence of polyphenol such as flavones, flavandiols, flavonoids, saponins, tannins and phenolic acids [10]. Anti-cancerous effects are due to the presence of polyphenols [11]. Antioxidant and antiinflammatory effect of green tea is due to the presence of catachins [12].

In addition to Ginger and Green Tea another plant is Neem (evergreen tropical tree) which is native to tropical, sub-tropical and semi-arid areas of Asia, Africa, European countries etc. It has antibacterial and anti-inflammatory effects. The antimicrobial properties of neem are due to the presence of two classes of Phytochemicals with their derivatives which are isoprenoids and nonisoprenoids [13]. The objectives of the study are to investigate the antibacterial and antifungal effect of ginger rhizome, green tea and neem leaves extract on the growth of Xanthomonas campestris and Alternaria alternata to find the potential uses of these extract in agriculture disease management on pathogens of economically important crops.

\section{Materials and Methods}

\section{Sample collection and pathogenic testing}

Disease free ginger rhizome powder and Green tree leaves were purchased from local market. Neem leaves were collected from a tree present in Bahauddin Zakariya University, Multan. Bacterial and fungal cultures used in this research were Xanthomonas campestris and Alternaria alternata, respectively which were obtained from "Faculty of Agricultural Sciences and Technology, Bahauddin Zakariya University, Multan". Nutrient agar was used to get pure culture of Xanthomonas campestris while Potato dextrose agar was used to get pure culture of Alternaria alternata.

\section{Extract Preparation}

For the assessment of antibacterial and antifungal effect of selected plant samples ethanolic and aqueous extract of each plant was prepared.

\section{Ethanol Extracts preparation}

For the preparation of ethanolic extract of ginger rhizome, $40 \mathrm{~g}$ of fully dried ginger powder was weighed and $120 \mathrm{ml}$ of $96 \%$ ethanol was added in it. To avoid ethanol evaporation beaker was covered with aluminum foil. Beaker was placed on the heat plate with magnetic stirrer for $20 \mathrm{~min}$ at $30^{\circ} \mathrm{C}$ to get a uniform mixture of ginger powder with ethanol. After stirring, the mixture was filtered. Obtained filtrate had excess ethanol which was evaporated by 
increasing the surface area of filtrate overnight and later on rotary vacuum evaporator was used to get more concentrated extract. Same protocol was applied for the preparation of ethanolic extract of other two plants that is neem and green tea. Crude extracts were preserved in the refrigerator at $0^{\circ} \mathrm{C}$ temperature for next experimental work.

\section{Aqueous Extract Preparation}

For the preparation of aqueous extract of all the plants, the $40 \mathrm{~g}$ of all plants were taken in the three separate beakers and filled with $120 \mathrm{ml}$ of distilled water. The beaker was then placed on the heat plate by putting the magnetic stirrer in it. Stirring was done for $20 \mathrm{~min}$ at $30^{\circ} \mathrm{C}$ for homogeneous mixing after that pure filtrate was obtained using paper filter. Excess water was evaporated by putting sample tubes in hot air oven for 24 hours at $80^{\circ} \mathrm{C}$ to get crude extract. After completing the extraction, the percentage yield of all the crude extracts was calculated by using following formula.

Percentage yield of plant extracts $=$ Weight of crude extract obtained in $\mathrm{g} \times 100 /$ total weight of plant sampling

\section{Media Preparation and Inoculation}

For inoculation of bacterial and fungal pathogen four large size petri plates were used for pouring media. For preparation of media, $28 \mathrm{~g}$ of Nutrient Agar and $39 \mathrm{~g}$ of Potato Dextrose Agar was mixed in 1 liter of distilled water, each in a separate jar. The jar was shaken gently to mix agar in water to get uniform mixture. Two petri plates were filled with "Nutrient Agar media" and other two were filled with "Potato Dextrose Agar media" and let the media to set for 1 hour. Each petri plate was divided into six equal sections for ethanolic and aqueous extract of each plant. All this process was done in the UV laminar air flow chamber to avoid any contamination.

\section{Antibacterial and Antifungal activity assay}

Antibacterial and antifungal potential of plant extracts were tested at two different stages of inoculum growth by applying the extract at the time of inoculation and after the growth of pathogen on media. Suspension of Xanthomonas campestris culture was prepared by using inoculum loop and suspension was mixed homogeneously. After that $2 \mu$ l of bacterial suspension for each nutrient agar plate was spread over the surface of nutrient media by using sterilized glass spreader. In the same way suspension of fungal culture was made and spread over the surface of each potato dextrose agar media plates. Agar Well Diffusion method [14] was used to assess inhibition.

\section{Minimum Inhibitory Concentration (MIC)}

MIC is the minimum concentration at which the growth of microbe is inhibited by antimicrobial compound. For measurement of MIC of all the plant extracts, micro broth dilution method was applied [14].

\section{Results and Discussion}

Prior to the period of scientific research in the field of plant pathology, control of plant diseases was a serious issue. Primordial human used plants and plants extract to make medicine, food and aromatic products. With advancement in technology and scientific research conventional agriculture practices were replaced by modern one. Modern agricultural practices include use of agrochemicals which although have ability to control diseases but side by side they are polluting environment [15] and cause serious health concerns for animals [16] and human beings [17]. With the passage of time plant pathogens become immune to these agrochemicals. Such resistant pathogens cannot be killed even high concentration of chemicals. Now scientists are trying to develop advanced agricultural techniques by which use of agrochemicals can be lessened and environment can be saved by damaging effects of such hazardous chemicals. In recent times a new idea has emerged in which plant extracts are being used as biocides [18]. Plants have abilities to produce secondary metabolites which may have special flavor or odor which may not be favorable for bacterial or fungal growth. These secondary metabolites are known as Phytochemicals [3] Phytochemicals present in plant extract are being used by scientists to control microbial pathogens which cause diseases in plants or animals. In the present study, aqueous and ethanolic extract of ginger, green tea and neem were prepared. Percentage yield of Ginger rhizome extract in ethanol was higher than extract in water. There was a less difference in yield of green tea extract in ethanol and water. However, neem extracts in ethanol was less than the water extracts (Table 1\&Figure 1).

\begin{tabular}{|c|c|c|c|c|c|c|c|c|}
\hline \multicolumn{2}{|c|}{ Table 1: Percentage yields of all Ethanolic and Aqueous extract of Ginger, Neem, Green Tea. } \\
\hline Sr No. & Plant Name & $\begin{array}{c}\text { Total weight } \\
\text { of plant } \\
\text { sample (g) }\end{array}$ & $\begin{array}{c}\text { Ethanol } \\
\text { Volume(ml) }\end{array}$ & $\begin{array}{c}\text { Distilled } \\
\text { water } \\
\text { Volume (ml) }\end{array}$ & $\begin{array}{c}\text { Weight of } \\
\text { crude extract } \\
\text { +ethanol (g) }\end{array}$ & $\begin{array}{c}\text { Weight of } \\
\text { crude extract } \\
\text { + distilled } \\
\text { water (g) }\end{array}$ & $\begin{array}{c}\text { \% yield in } \\
\text { Ethanol }\end{array}$ & $\begin{array}{c}\text { \% yield in } \\
\text { Distilled } \\
\text { water }\end{array}$ \\
\hline 1 & Ginger rhizome & 40 & 120 & 120 & 1.34 & 0.85 & 3.35 & 2.1 \\
\hline 2 & Green tea leaves & 40 & 120 & 120 & 1.94 & 1.64 & 4.85 & 4.1 \\
\hline 3 & Neem leaves & 40 & 120 & 120 & 2 & 2.12 & 5 & 5.3 \\
\hline
\end{tabular}




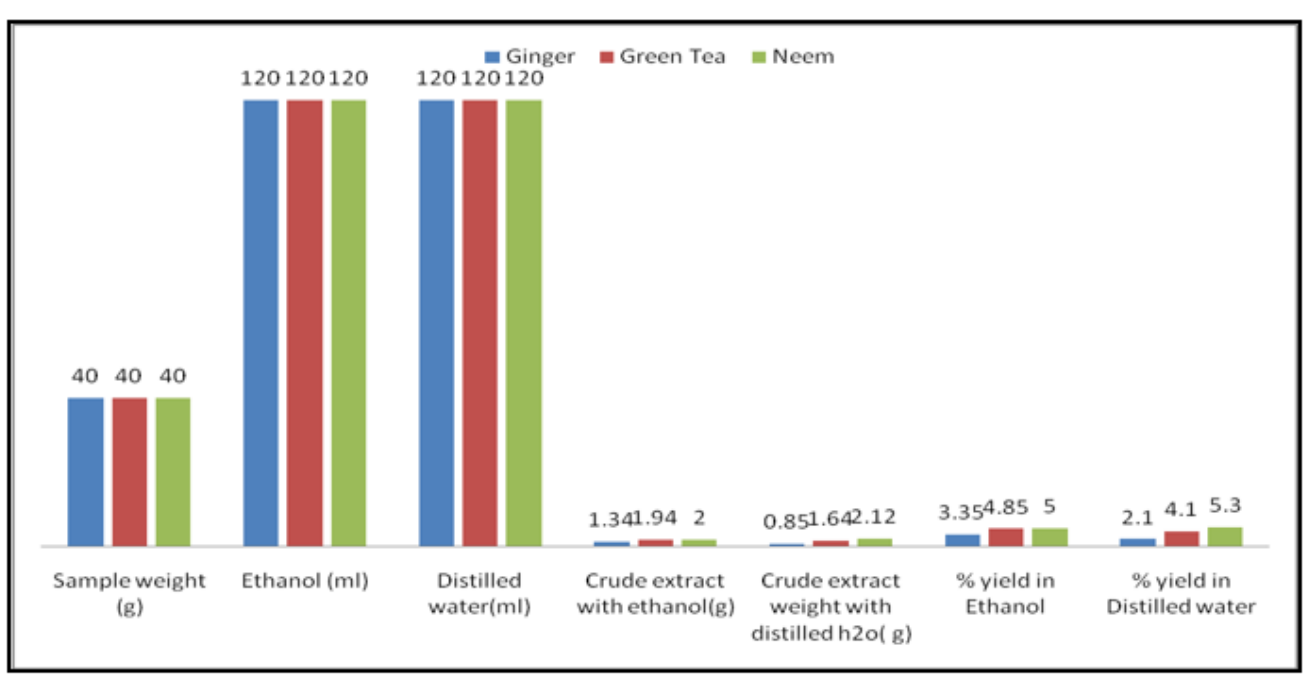

Figure 1: Percentage yields of all Ethanolic and Aqueous extract of Ginger, Neem, Green Tea.

When extract of plants were applied before growth of bacterial and fungal pathogens at the time of inoculation, ethanolic extract of green tea showed highest inhibition zone on Xanthomonas campestris was $12.5 \pm 1.0 \mathrm{~mm}$ while lowest inhibition zone of $6.0 \pm 0.5 \mathrm{~mm}$ was due to the aqueous extract of green tea. Antimicrobial activity of other extracts was in between these two ranges. Antibacterial and antifungal activity of ethanolic extract of ginger rhizome and neem leaves was $11.5 \pm 1.0,6.0 \pm 1.0,11.5 \pm 1.0$, and $7.5 \pm 0.5$, respectively. It was also observed that the ethanolic extracts of all the plants showed higher antibacterial and antifungal activity than the aqueous extract. Table 2 along with Figures $2 \& 3$ showing antibacterial and antifungal activity of all plant extracts when applied before growth at the time of inoculation. In second case, when extract was applied after $24 \mathrm{hrs}$ of bacterial and fungal growth, the results of inhibition were different. Aqueous extract of ginger rhizome showed no antifungal activity while antibacterial activity was $3.0 \pm 0.5 \mathrm{~mm}$. The lowest antibacterial activity was showed by the ethanolic extract of neem and the lowest antifungal activity was also due to the aqueous extract of neem with the inhibition zone of $0.8 \pm 1.0$ and $1.0 \pm 0.5 \mathrm{~mm}$, respectively. Highest antibacterial and antifungal activity was shown by aqueous extract of green tea leaves with the inhibition zone of $12.5 \pm 1.0$ and $3.0 \pm 0.6 \mathrm{~mm}$, respectively. However, the antibacterial and antifungal activity of ethanolic and ginger extract was in between these ranges. Table 3 along with Figures $4 \& 5$ showing the antibacterial and antifungal activity of all the plant extracts applied after the growth of bacterial and fungal inoculum.

\section{Ethanolic extract $\quad$ Aqueous extract}

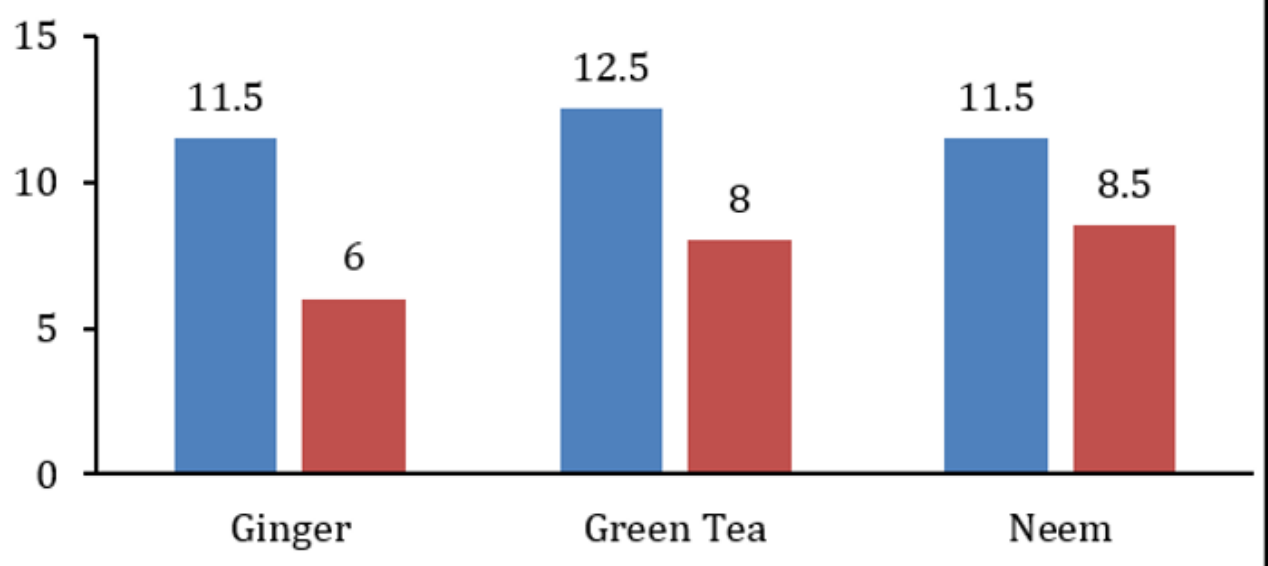

Figure 2: Inhibition zone for Xanthomonas campestris $(\mathrm{mm})$ before growth. 

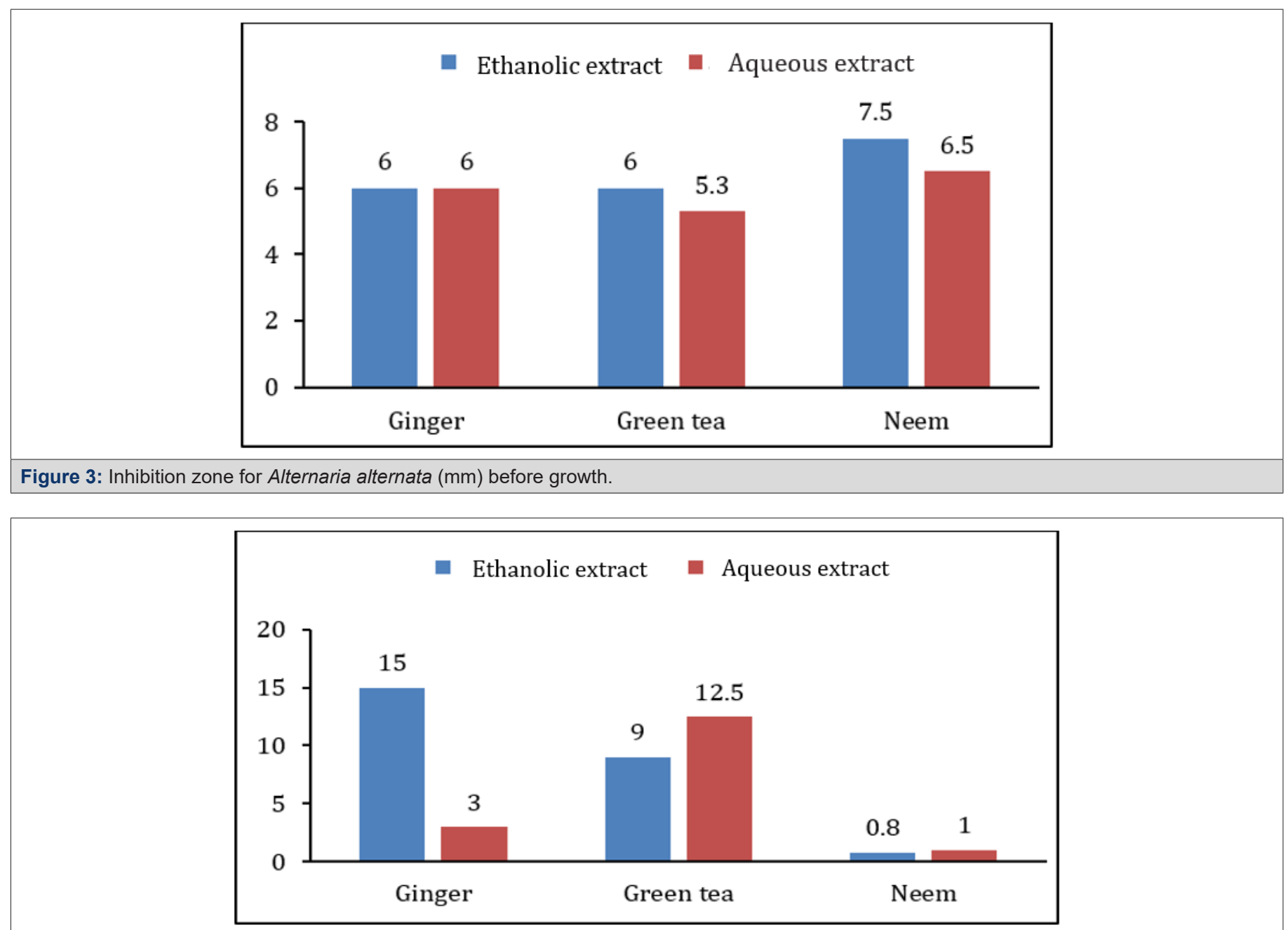

Figure 4: Inhibition zone for Xanthomonas campestris ( $\mathrm{mm}$ ) after inoculum growth.

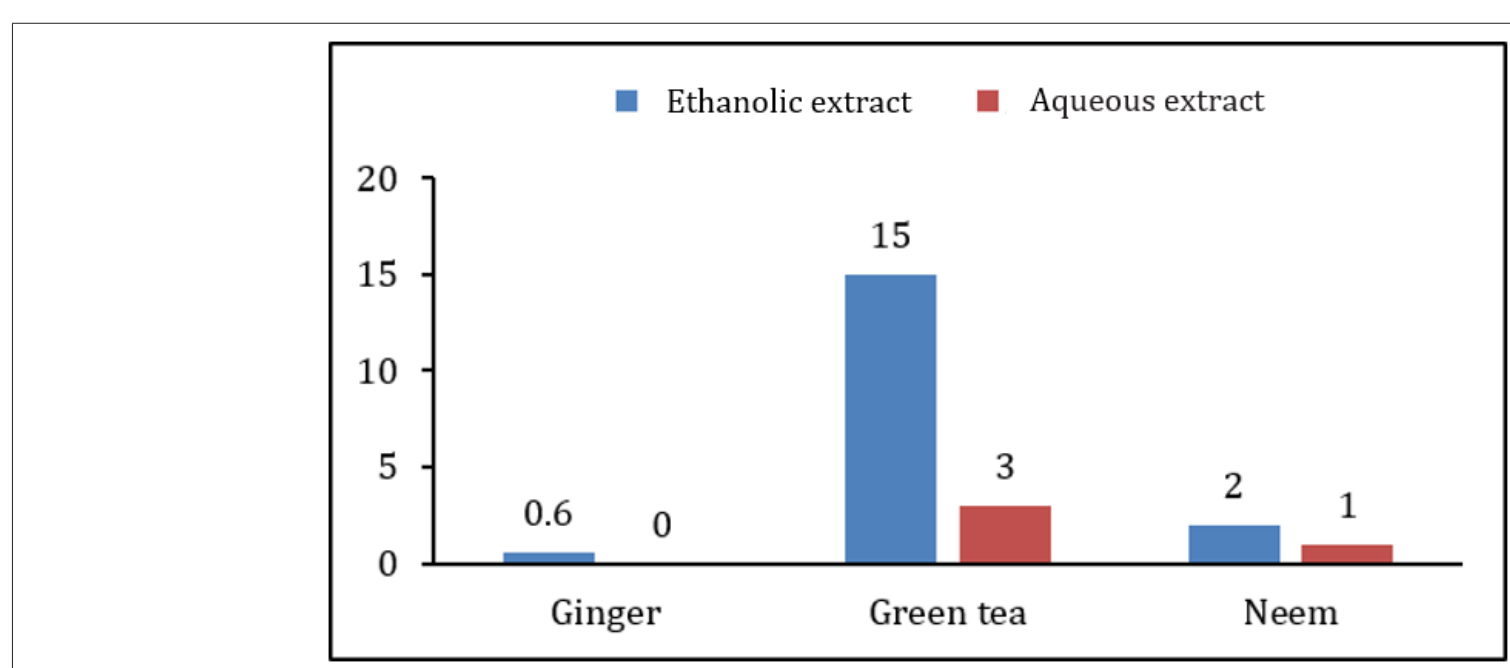

Figure 5: Inhibition zone for Alternaria alternata $(\mathrm{mm})$ after 24 hours inoculation. 


\begin{tabular}{|c|c|c|c|c|}
\hline \multirow[b]{2}{*}{ Sr. No. } & \multirow[b]{2}{*}{ Plant Name } & \multirow[b]{2}{*}{ Extract Type } & \multicolumn{2}{|c|}{ Antimicrobial activity after growth } \\
\hline & & & $\begin{array}{l}\text { Inhibition zone for Xanthomonas } \\
\text { campestris ( } \mathrm{mm})\end{array}$ & $\begin{array}{c}\text { Inhibition zone for } \\
\text { Alternaria alternata }(\mathrm{mm})\end{array}$ \\
\hline \multirow{2}{*}{1} & \multirow{2}{*}{$\begin{array}{l}\text { Zingiber officinale (Ginger } \\
\text { rhizome) }\end{array}$} & Ethanolic Extract & $1.5 \pm 0.3$ & $0.6 \pm 0.5$ \\
\hline & & Aqueous Extract & $3.0 \pm 0.5$ & No Inhibition \\
\hline \multirow{2}{*}{2} & \multirow{2}{*}{$\begin{array}{c}\text { Camellia sinensis (Green tea } \\
\text { leave) }\end{array}$} & Ethanolic Extract & $9.0 \pm 1.0$ & $1.5 \pm 0.5$ \\
\hline & & Aqueous Extract & $12.5 \pm 1.0$ & $3.0 \pm 0.6$ \\
\hline \multirow{2}{*}{3} & \multirow{2}{*}{$\begin{array}{c}\text { Azadrichta indica (Neem } \\
\text { leaves) }\end{array}$} & Ethanolic Extract & $0.8 \pm 1.0$ & $2.0 \pm 0.5$ \\
\hline & & Aqueous Extract & $1.0 \pm 0.3$ & $1.0 \pm 0.5$ \\
\hline
\end{tabular}

Table 3: Measurements of inhibition zone after inoculum growth.

\begin{tabular}{|c|c|c|c|c|}
\hline \multirow[b]{2}{*}{ Sr. No. } & \multirow[b]{2}{*}{ Plant Name } & \multirow[b]{2}{*}{ Extract Type } & \multicolumn{2}{|c|}{ Antimicrobial activity after growth } \\
\hline & & & $\begin{array}{l}\text { Inhibition zone for Xanthomonas } \\
\text { campestris ( } \mathrm{mm})\end{array}$ & $\begin{array}{c}\text { Inhibition zone for } \\
\text { Alternaria alternata }(\mathrm{mm})\end{array}$ \\
\hline \multirow{2}{*}{1} & \multirow{2}{*}{$\begin{array}{l}\text { Zingiber officinale (Ginger } \\
\text { rhizome) }\end{array}$} & Ethanolic Extract & $1.5 \pm 0.3$ & $0.6 \pm 0.5$ \\
\hline & & Aqueous Extract & $3.0 \pm 0.5$ & No Inhibition \\
\hline \multirow{2}{*}{2} & \multirow{2}{*}{$\begin{array}{c}\text { Camellia sinensis (Green tea } \\
\text { leave) }\end{array}$} & Ethanolic Extract & $9.0 \pm 1.0$ & $1.5 \pm 0.5$ \\
\hline & & Aqueous Extract & $12.5 \pm 1.0$ & $3.0 \pm 0.6$ \\
\hline \multirow{2}{*}{3} & \multirow{2}{*}{$\begin{array}{l}\text { Azadrichta indica (Neem } \\
\text { leaves) }\end{array}$} & Ethanolic Extract & $0.8 \pm 1.0$ & \\
\hline & & Aqueous Extract & $1.0 \pm 0.3$ & $1.0 \pm 0.5$ \\
\hline
\end{tabular}

MIC of ethanolic extract of all plants was lower than MIC of aqueous extract. It was also observed that antibacterial activity of all plant extracts was higher than antifungal effect. Highest MIC value for bacterial pathogen was $108.3 \mathrm{mg} / \mathrm{ml}$ by aqueous extract of ginger rhizome while lowest MIC value was $25 \mathrm{mg} / \mathrm{ml}$ due to antibacterial effect of ethanolic extract of neem leaves. All other plant extracts have MIC values in between these two ranges for Xanthomonas campestris. Fungal pathogen showed more resistance against antifungal effect of tested plant extracts. MIC values of aqueous extract of ginger rhizome and green tea leaves was $158.3 \mathrm{mg} / \mathrm{ml}$ for Alternaria alternata, which is the highest MIC for fungal pathogen. However, the lowest MIC value for Alternaria alternata was $75 \mathrm{mg} / \mathrm{ml}$ by ethanolic extract of neem leaves. The others extract showed antifungal MIC value in between these two ranges (Table $4 \&$ Figures $6 \&$ 7). Microbial pathogens either belong to bacterial or fungal group [7]. Worldwide almost 400,000 plant species have Phytochemicals [6]. Plant extracts of more than 8000 species have phenolic characteristics [7]. Herbs such as coriander, basil, thyme, onion, ginger, turmeric, garlic etc. are most commonly used to get Phytochemicals in higher quantity, which have antibacterial, antifungal and antiviral properties [5]. So, their effects on antifungal or antibacterial growth of plant pathogens will be helpful for our cropping system. Adoption of biological methods (like biocides) to control diseases will not only be very beneficial for small farmers to design disease control strategies but will be cost effective as well.

\begin{tabular}{|c|c|c|c|c|}
\hline Sr. No. & Plant Name & Extract Type & $\begin{array}{l}\text { MIC for Xanthomonas } \\
\text { campestris } \mathrm{Mg} / \mathrm{ml}\end{array}$ & $\begin{array}{c}\text { MIC for Alternaria } \\
\text { alternata } \mathrm{Mg} / \mathrm{ml}\end{array}$ \\
\hline \multirow{2}{*}{1} & \multirow{2}{*}{$\begin{array}{l}\text { Zingiber officinale (Ginger } \\
\text { rhizome) }\end{array}$} & Ethanolic Extract & 58.3 & 141.7 \\
\hline & & Aqueous Extract & 108.3 & 158.3 \\
\hline \multirow{2}{*}{2} & \multirow{2}{*}{$\begin{array}{c}\text { Camellia sinensis (Green tea } \\
\text { leave) }\end{array}$} & Ethanolic Extract & 41.7 & 125 \\
\hline & & Aqueous Extract & 58.3 & 158.3 \\
\hline \multirow{2}{*}{3} & \multirow{2}{*}{$\begin{array}{c}\text { Azadrichta indica (Neem } \\
\text { leaves) }\end{array}$} & Ethanolic Extract & 25 & 75 \\
\hline & & Aqueous Extract & 91.7 & 91.7 \\
\hline
\end{tabular}




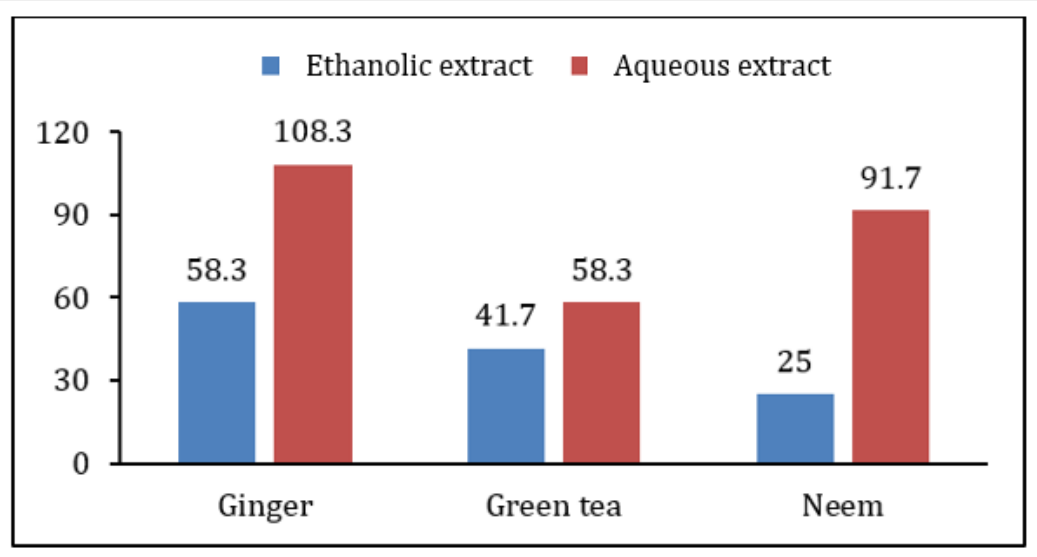

Figure 6: MIC for Xanthomonas campestris $\mathrm{mg} / \mathrm{ml}$.

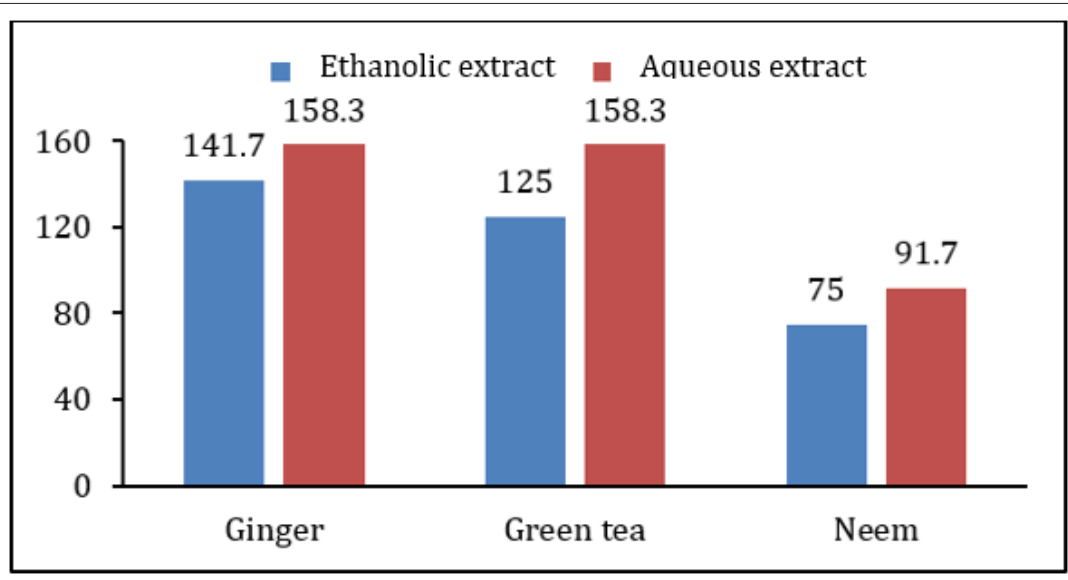

Figure 7: MIC for Alternaria alternata $\mathrm{mg} / \mathrm{ml}$.

\section{Conclusion}

Results of present study provided information about percentage yield, antimicrobial and antifungal activity measurement and minimum inhibitory concentration in both aqueous and ethanolic extracts. Based on elucidation of this study on antimicrobial/ antifungal activities of ginger, neem and green tea it can be inferred that these spices can be used as effective antimicrobial and antifungal force against Xanthomonas campestris and Alternaria alternata. Amalgamation of their extracts can impart additional or collaborative inhibitory outcomes making them supplementary valuable as antimicrobial/antifungal agents. Although conventionally, spices herbs and plants are used for food preservation and as disinfectant, it is essential to set up their antimicrobial/antifungal qualities by methodizing their concentrations in amalgam extracts so that most advantageous inhibitory effect may be acquired. Advance researches are obligatory to explore interaction and microbial growth inhibition mechanisms f divergent phytochemicals from different plants. The awareness on effectiveness of pooled extracts can be expanded from food implementations to pharmacological and chemical field.

\section{Acknowledgements}

A special Thanks to Faculty of Agricultural Sciences and Technology, Bahauddin Zakariya University, Multan for providing pathogens.

\section{Conflict of Interest}

The authors have declared no conflict of interest.

\section{References}

1. Fawzi E, Khalil A, Afifi A (2009) Antifungal effect of some plant extracts on Alternaria alternata and Fusarium oxysporum. African Journal of Biotechnology 8 (11).

2. Shabana YM, Abdalla ME, Shahin AA, El-Sawy MM, Draz IS, et al. (2017) Efficacy of plant extracts in controlling wheat leaf rust disease caused by Puccinia triticina. Egyptian Journal of Basic and Applied Sciences 4(1): 67-73.

3. Akintobi O, Onoh C, Ogele J, Idowu A, Ojo O, et al. (2013) Antimicrobial activity of Zingiber officinale (ginger) extract against some selected pathogenic bacteria. Nature and science11: 7-15.

4. Choudhury D, Anand YR, Kundu S, Nath R, Kole RK, et al. (2017) Effect of plant extracts against sheath blight of rice caused by Rhizoctonia solani. J Pharmacogn Phytochem6(4): 399-404. 
5. Panpatil VV, Tattari S, Kota N, Nimgulkar C, Polasa K (2013) In vitro evaluation on antioxidant and antimicrobial activity of spice extracts of ginger, turmeric and garlic. J. Pharmacogn. Phytochem.2 (3): 143-148.

6. Jangam SV, Thorat BN (2010) Optimization of spray drying of ginger extract. Drying Technology 28(12): 1426-1434.

7. Altemimi A, Lakhssassi N, Baharlouei A, Watson DG, Lightfoot DA (2017) Phytochemicals: Extraction, isolation, and identification of bioactive compounds from plant extracts. Plants 6(4): 42.

8. Park M, Bae J, Lee DS (2008) Antibacterial activity of [10]-gingerol and [12]-gingerol isolated from ginger rhizome against periodontal bacteria. Phytother Res 22(11): 1446-1449.

9. Ficker C, Smith M, Akpagana K, Gbeassor M, Zhang J, et al. (2003) Bioassay-guided isolation and identification of antifungal compounds from ginger. Phytother Res 17(8): 897-902.

10. Cushnie TT, Lamb AJ (2005) Antimicrobial activity of flavonoids. Int Antimicrob Agents 26(5): 343-356.

11. Nadifah F, Sari RM (2016) The effect of ginger (Zingiber officinale) and green tea (Camellia sinensis) against bacteria growth on soymilk. AIP Conference Proceedings. 1744(1): p. 020022: AIP Publishing.

12. Ahmed S, Steppy JR (2013) Green Tea: Plants, Processing, Manufacturing and Production.
13. Subapriya R, Nagini S (2005) Medicinal properties of neem leaves: a review. Curr Med Chem Anticancer Agents 5(2): 149-156.

14. Baljeet S, Simmy G, Ritika Y, Roshanlal Y (2015) Antimicrobial activity of individual and combined extracts of selected spices against some pathogenic and food spoilage microorganisms. International Food Research Journal 22(6): 2594-2600.

15. Domsch K, Jagnow G, Anderson T H (1983) An ecological concept for the assessment of side-effects of agrochemicals on soil microorganisms. Residue Reviews 86: 65-105.

16. Bunn K, Thompson H, Tarrant K (1996) Effects of agrochemicals on the immune systems of earthworms. Bulletin of environmental contamination and toxicology 57: 632-639.

17. Kesavachandran CN, Fareed M, Pathak MK, Bihari V, Mathur N, et al (2009) Adverse health effects of pesticides in agrarian populations of developing countries. Rev Environ Contam Toxicol 200: 33-52.

18. Ahmed S, Ahmad M, Swami BL, Ikram S (2016) A review on plants extract mediated synthesis of silver nanoparticles for antimicrobial applications: a green expertise. J ADV Res 7(1): 17-28. 